\title{
A Cooriginariedade Entre Direitos Humanos E Soberania Popular: a Crítica de Habermas a Kant e Rousseau
}

Luiz Repa $a^{1}$

\begin{abstract}
RESUMO: O texto busca compreender e avaliar as influências das filosofias políticas de Rousseau e Kant no pensamento habermasiano. Ele se atém sobretudo à ideia fundamental de Direito e democracia, segundo a qual há uma cooriginariedade lógica entre direitos humanos, interpretados como direitos fundamentais de liberdade individual, e a soberania popular, interpretada como direitos políticos de participação e comunicação, no processo de formação pública da opiniāo e vontade. Defende-se que a crítica habermasiana a Rousseau e a Kant se deve ao projeto de radicalização da democracia, para o qual as contribuiçōes dos dois filósofos apresentam ainda alguns obstáculos. Porém, ao mesmo tempo, pode-se dizer que, segundo Habermas, a contribuição de um serve para sanar os problemas presentes na contribuição do outro.
\end{abstract}

PALAVRAS-CHAVE: Direitos fundamentais. Soberania popular. Democracia. Autonomia.

A ideia segundo a qual há uma cooriginariedade entre os direitos fundamentais que garantem a autonomia privada das pessoas jurídicas e os direitos fundamentais que garantem a autonomia pública dos cidadãos constitui, sem dúvida, o núcleo normativo da teoria habermasiana do direito e da democracia. Os direitos de liberdade de ação e os direitos de participação política são articulados como condiçôes recíprocas entre si. Ou seja, uns são condiçôes de possibilidade dos outros, de modo que toda tentativa de estabelecer uma hierarquia e uma subordinação entre eles afeta o seu nexo interno. Porém, a história da filosofia política moderna e contemporânea ilustraria, para Habermas, diversas tentativas desse tipo. De um lado, a tradição liberal

\footnotetext{
${ }^{1}$ Professor adjunto da Universidade Federal do Paraná e pesquisador do núcleo Direito e Democracia do CEBRAP. Publicou A transformação da filosofia em Jürgen Habermas: os papéis de reconstrução, interpretaçâo e crítica (Esfera Pública, 2008) e coorganizou Habermas e a reconstrução (Papirus, 2012).
} 
enfatiza a dignidade própria, em última instância moral dos direitos humanos que traduzem a autonomia privada frente ao processo político democrático, delimitando desde o início seu alcance. De outro lado, o republicanismo tende a subordinar os direitos humanos à práxis da autolegislação do povo, na qual se concentra a autonomia pública dos cidadãos.

Habermas não pretende, todavia, nenhuma originalidade total para seu intento, pois já em Rousseau e Kant seria possível enxergar o objetivo de pensar, a partir do conceito de autonomia, a interpretação mútua entre os dois princípios, direitos humanos e soberania popular. No entanto, o modo como ele é efetivado por ambos os filósofos se torna o alvo da crítica habermasiana. Rousseau teria se aproximado mais da tradição republicana, sublinhando os fundamentos éticos concretos da soberania, enquanto Kant, ao contrário, tenderia para o liberalismo, ao fazer com que os direitos humanos moralmente fundados precedessem a autolegislação dos cidadãos. O que não é atingido por nenhum deles seria a interdependência simétrica entre os dois princípios, em torno dos quais se perpetua o conflito entre liberais e republicanos.

De certa maneira, a tentativa habermasiana consiste em mostrar a parcialidade de cada uma dessas abordagens, enfatizando sua possível complementaridade e reciprocidade. Assim, ela pode ser vista também como uma maneira de corrigir Kant por meio de Rousseau, e de Rousseau por meio de Kant. Esse estranho exercício de correçóes recíprocas só pode ser efetivado a partir de uma instância que, desde o começo, se situa além das partes que concorrem parcialmente entre si. Apresentarei, de início, por que Habermas considera que Kant e Rousseau, de maneiras diferentes, se avizinham da ideia de cooriginariedade e por que não a alcançaram efetivamente. Em seguida, demonstrarei como o próprio Habermas pretende solucionar o problema, para finalmente apontar como sua estratégia significa suplantar a concorrência entre o princípio dos direitos humanos e o da soberania popular.

Em Direito e Democracia, Habermas parte do diagnóstico de que, na modernidade, após a dissolução da substância normativa do ethos próprio das imagens religiosas e metafísicas de mundo, resulta um pluralismo axiológico cada vez mais crescente, em face do qual somente dois princípios seriam capazes de legitimar o direito positivo. Trata-se justamente do princípio dos direitos humanos, interpretados na tradição jusnaturalista como direitos naturais, fundamentados moralmente pela razão, e o princípio da soberania do povo, traduzindo-se como expressão da autorrealização ética de uma comunidade política historicamente dada e, por isso, partilhando certos 
valores que alicerçam sua identidade coletiva. Esses dois princípios foram e continuam a ser interpretados e postos em concorrência tanto pelo liberalismo como pelo republicanismo. De um ponto de vista liberal, do qual Locke é um caso exemplar, é preciso estabelecer limites jurídicos para o exercício da vontade do povo, os quais são dados pelo primado dos direitos humanos pré-políticos. De um ponto de vista republicano, comum ao humanismo renascentista, nenhuma norma pode restringir a vontade soberana e o projeto de autorrealização ético-política do povo. Na linha liberal impóe-se, portanto, o programa de legitimar o direito positivo com base em normas que náo são, na origem, jurídicas, mas dadas como moralmente justificadas. A moral embutida na ideia de direitos naturais determinaria a práxis legislativa de criação de direito, exigindo a positivação desses direitos naturais como normas constitucionais. $\mathrm{Na}$ linha republicana, a legitimidade do direito positivo derivaria unicamente das condiçôes soberanas do exercício da vontade do povo, alimentando-se das virtudes cívicas que unem a coletividade política (cf. também HABERMAS, 1996a).

Rousseau e Kant, por sua vez, representariam duas tentativas distintas de mostrar uma possível complementaridade entre os dois princípios, a partir do conceito de autonomia.

Rousseau parte da constituição da autonomia civil e produz a fortiori um nexo interno entre a soberania popular e os direitos humanos. Uma vez que a vontade soberana do povo só pode se exteriorizar na linguagem de leis universais e abstratas, está inscrita nela por origem [von Haus aus] aquele direito a liberdades subjetivas iguais que Kant antepóe, como direito humano moralmente fundamentado, à formação da vontade política. (HABERMAS, 1994, p. 131).

Embora Habermas não desenvolva em detalhes sua interpretação de Rousseau, a passagem permite enfatizar duas coisas. Em primeiro lugar, que o ponto de partida efetivo de Rousseau, ao contrário de seus antecessores na tradição contratualista (Hobbes e Locke, em especial), não é o estado de natureza na qual os homens poderiam determinar por sua própria razão direitos e leis naturais. De fato, é chamativo que o Contrat social não dedique nem mesmo um capítulo para o estado de natureza e para os motivos que exigem a saída dele. O motivo é basicamente um só e, ainda assim, a título de suposição. É possível pensar um ponto de evolução do estado de natureza em que os obstáculos para a conservaçáo de cada um sejam maiores do que as 
forças individuais para se conservar (cf. ROUSSEAU, 2001, I, VI). Rousseau não oferece nenhuma explicação sobre tais obstáculos. Isso se deve não simplesmente ao fato de o Discurso sobre a desigualdade conter em pormenor as razôes dessa evolução. Antes, importa saber em que condiçóes é legítimo um pacto social que não só garanta a conservação de cada um, mas também a liberdade de cada um, entendida, de início, de maneira minimalista por assim dizer, como direito natural e a ser transformada em liberdade civil.

O outro ponto é mais importante, já que indica como Rousseau pôde estabelecer um nexo interno entre os direitos humanos e a soberania popular, que é, a princípio, ilimitada. É chamativo aqui ainda que Habermas contraria fortemente toda a crítica dirigida a Rousseau por seu conceito de soberania ilimitada ${ }^{2}$. A princípio, ele parece ter em mente a seguinte linha de interpretação. A soberania, sendo o exercício da vontade geral, não pode ser colocada além dela. Como a vontade geral é a vontade do corpo político, e este se constitui de todos os associados reunidos em um povo, o soberano nada é senão um ser coletivo constituído por todos. Disso resulta que ninguém está fora da dupla relação súdito/cidadão, portanto, que ninguém está desobrigado das decisóes do soberano enquanto súdito. Além disso, tanto a obediência à lei como a participação em sua autoria é feita em total igualdade, de modo que, para a deliberação política, todos têm as mesmas condiçôes de participação e, para a obediência civil, a mesma igualdade de direitos e deveres. Dessa dupla igualdade, relativa à dupla posição de cada membro, "[...] cada um se submete necessariamente às condiçôes que ele impóe aos outros" (ROUSSEAU, 2001, p. 72). A generalidade formal da lei impóe a reciprocidade e a equidade na consideração de todos os interesses envolvidos. Por sua própria constituição, a autoridade soberana não tem outra linguagem senão a linguagem do direito formal e igual. Dessa maneira, portanto, a soberania encontra uma condição na sua própria linguagem. Ela continua absoluta, mas condicionada por sua única maneira de expressão, que é a lei geral. Os direitos individuais não constituem um ordenamento prévio que comandaria toda a constituição soberana, mas são o resultado dela, dada a generalidade e a igualdade da lei, e dada a identidade entre súdito e cidadão. "O exercício da soberania popular assegura ao mesmo tempo os direitos humanos" (HABERMAS, 1988/1994, p. 611).

O conceito de autonomia kantiano seria, como dá a entender Habermas, mais complexo que o de Rousseau, na medida em que ele não se

\footnotetext{
${ }^{2}$ A despeito disso, cf. os aspectos críticos da recepção "simpática" de Rousseau por parte de Habermas, segundo a análise de DUTRA, 2012.
} 
expressa apenas pelo princípio da democracia ${ }^{3}$ (vontade unida do povo), mas também no princípio moral (o imperativo categórico na ética) e o princípio do direito (a lei universal do direito). É na articulação desses três princípios que, para Habermas, permanece obscura - que se fundamentaria a intuição kantiana da cooriginariedade de direitos humanos e soberania popular.

Visto que a questão sobre a legitimidade das leis que asseguram a liberdade tem de encontrar uma resposta no interior do direito positivo, o contrato social faz com que o princípio do direito domine, na medida em que tal contrato vincula a formação da vontade política do legislador às condiçóes de um procedimento democrático, sob as quais os resultados alcançados conforme o procedimento expressam per se a vontade concordante ou o consenso racional de todos os participantes. (HABERMAS, 1994, p. 123).

O princípio do direito aparece de início como o elemento intermediário entre a moral e a democracia, porque, exigindo a coexistência ou limitaçáo mútua das liberdades individuais segundo uma lei universal, combina o único direito inato a liberdades iguais com sua positivação jurídica legitimada pelo princípio da democracia, o qual torna possíveis leis universais. Reportandose ao texto de Kant "Sobre a expressão corrente", Habermas considera que os direitos subjetivos (liberdade de cada um como homem, e igualdade de cada um como súdito) recebem primeiro uma fundamentação com base na autonomia moral de cada um, para depois serem reencontrados e garantidos pela independência de cada um como cidadão, ou seja, pela autonomia civil. Dessa maneira, delineia-se em Kant um sistema de direitos fundamentais, que sustentam o direito de liberdade, o direito de igualdade e o direito de cidadania. Os dois primeiros se fundamentariam moralmente, mesmo que se liguem a uma autorização para a coerção externa, pelo fato de advir ao homem, nas palavras de Kant, "[...] graças unicamente à sua humanidade" e na qualidade de serem "inatos" e "inalienáveis" (KANT, MS, AA, VI, p, 237; UG, AK, VIII, p. 287). Embora o conceito kantiano de direito em seu aspecto legal seja, para Habermas, como veremos a seguir, a chave para compreender os direitos subjetivos a iguais liberdades de ação, ele se encontraria, no seu entender, ainda muito preso ao princípio moral, o qual é aplicado às relações exteriores, revestindo-se as normas com a autorização de coerção ${ }^{4}$.

\footnotetext{
${ }^{3}$ Naturalmente, Habermas se refere ao princípio da constituição republicana em Kant.

${ }^{4}$ Contra essa leitura, cf. MAUS, 2002.
} 
Os direitos de cidadania, por sua vez, remetem ao procedimento democrático, configurado juridicamente no contrato originário, o qual possibilitaria o segundo passo da positivação dos direitos de liberdade e igualdade. Conforme Kant, "[...] nenhuma outra vontade é possível a não ser a do povo reunido (já que todos decidem sobre todos, portanto cada um sobre si mesmo)" (KANT, UG, AA. VIII, p. 294). O procedimento democrático, vinculado ao princípio do direito, impóe um ponto de vista a partir do qual é preciso considerar o interesse simétrico de todos, compatibilizando-o com a liberdade e igualdade individuais. $\mathrm{O}$ resultado do procedimento democrático entra em acordo com o que é dado previamente ao contrato originário, porque, segundo Habermas, Kant teria partido da ideia "[...] de que ninguém poderia, no exercício de sua autonomia civil, consentir com leis que se chocariam contra sua autonomia privada garantida pelo direito natural" (HABERMAS, 1994, p. 131).

Com isso, Habermas parece atribuir a Kant uma solução análoga à de Rousseau: o exercício da cidadania, uma vez que é determinado pelo direito, forçaria a um respeito recíproco pela autonomia privada de cada um (cf. HABERMAS, 1988/1994, p. 611). A igualdade de participaçáo e a igualdade perante a lei tornam o procedimento democrático um teste de universalização de normas jurídicas que resulta no reconhecimento dos direitos subjetivos iguais de liberdade. Mas, além disso, o procedimento democrático também se vincula ao princípio moral, na medida em que a forma da lei geral expressa um teste de generalização da razão que examina leis, ou seja, de tal modo que os cidadãos podem fazer igualmente uso de argumentos morais para a justificação das leis.

As duas soluçóes para o problema de compatibilizar direitos humanos e soberania popular são, no entanto, criticadas por Habermas, porque, no fundo, tanto em Rousseau como em Kant, existiria ainda uma "[...] relação de concorrência inconfessada" (HABERMAS, 1994, p. 123). Ela se mostraria a partir de uma leitura ética, no caso de Rousseau, da ideia de autolegislaçáo e de uma leitura moral do direito em geral no caso de Kant. No primeiro caso, Habermas se reporta à célebre e enigmática conversão de indivíduos preocupados unicamente com seus interesses privados em cidadãos ciosos pelo bem comum, no momento mesmo de constituição da soberania do povo. Além disso, as virtudes políticas já existentes em uma determinada comunidade deveriam ser o cerne normativo da legislação. Um enfraquecimento da substância ética do povo, ou seja, a distância maior entre os costumes e as leis, causado por um maior número de pessoas, exige, inversamente, uma maior 
coerção por parte do Estado. De um lado, portanto, a radicalidade do projeto democrático de Rousseau - é o que se pode depreender da crítica de Habermas - se perderia, ao contar com uma unidade ou mesmo uma homogeneidade ética prévia a respeito do que vem a ser o bem comum, ou ao passar por cima de uma mediação não forçada entre a orientação pelo bem comum e os interesses das pessoas privadas. Se essa mediação é garantida pelo princípio do direito (a universalidade e igualdade das leis gerais), sua insuficiência reside no fato de que o simples caráter formal, sua generalidade semântica, nada diz a respeito do conteúdo normativo dos direitos humanos. A simples forma de leis gerais não garante sua validade.

No caso de Kant, o problema não está em contar com um princípio moral, unicamente a partir do qual se poderia avaliar se o que é bom para nós é do interesse simétrico da cada um. O ponto de vista moral, dado com o imperativo categórico, permite a fundamentação racional do conteúdo normativo dos direitos humanos ${ }^{5}$. O problemático, para Habermas, reside no fato de a consideração moral já decidir previamente quais poderiam ser os direitos humanos em termos de direito natural privado, que apenas aguardam sua positivação por leis públicas. Mesmo que eles possam ser alcançados posteriormente, no interior da construção do contrato originário, o sentido do procedimento democrático perde igualmente em radicalidade, se a orientaçáo normativa é, por assim dizer, já introduzida de fora da própria práxis legislativa e acatada pelos cidadáos. De certo modo, essa práxis apenas justificaria o que é desde sempre já justificado.

Vê-se que no essencial a crítica de Habermas sempre tem o mesmo sentido: tanto Rousseau como Kant não fazem justiça à práxis democrática, ao processo de formação da vontade e da opinião, seja porque um compreende essa práxis de um ponto de vista ético e não reconhece a natureza do procedimento capaz de legitimar os direitos subjetivos, seja porque o outro pré-determina de um ponto de vista moral os direitos que serão justificados na esfera política. "O buscado nexo interno entre soberania popular e direitos humanos reside no conteúdo normativo de um modo de exercício da autonomia política, que não é já assegurado pela forma de leis gerais, mas somente pela forma de comunicação da formação discursiva da opinião e da vontade" (HABERMAS,

\footnotetext{
${ }^{5}$ Isso não significa que a teoria do discurso não proponha uma interpretação diferente do princípio moral. Segundo Habermas, o teste universalizador de normas morais propiciado pelo imperativo categórico se restringe ao ponto de vista da consciência moral de cada um, o que impede a avaliaçáo justa de todos os interesses envolvidos pelas normas. O discurso moral tem de se dar de maneira intersubjetiva. Cf. HABERMAS, 1989, p. 87 ss.
} 
1994, p. 133). Como não poderia deixar de ser, a insuficiência da abordagem rousseauísta e da kantiana se deve ao fato de que elas se movem no interior do paradigma da filosofia da consciência, de modo que a autonomia é recortada à dimensão seja do sujeito eu, seja do sujeito povo.

Uma tal crítica a Rousseau e Kant poderia sem dúvida ser contestada lembrando-se as exigências de participação no processo deliberativo, no caso de Rousseau, e a exigências do princípio de publicidade na discussão sobre o processo legislativo, no caso de Kant, como pontua Ingeborg Maus (2002, p. 112). De fato, Habermas não faz nenhuma referência aos aspectos propriamente deliberativos em Rousseau, como os direitos de "[...] opinar, propor, analisar, discutir, que o Governo tem sempre o grande cuidado de não reservar senão a seus membros" (ROUSSEAU, 2001, IV, I). Por outro lado, também não se pode esquecer que o próprio Contrat social não parece conferir um peso especial à discussão pública, uma vez que conta com uma formação da opinião por parte de cada cidadão como que isoladamente: "Se, quando o povo suficientemente informado delibera, os Cidadãos não tivessem nenhuma comunicação entre eles, do grande número de pequenas diferenças resultaria sempre a vontade geral, e a deliberação seria sempre boa" (ROUSSEAU, 2001, II, III). Por deliberação, Rousseau parece entender, como acentua Bernard Manin, um processo de decisão baseada na convergência de opiniốes constituídas de antemão e não em primeira linha um processo de formação da opinião que passa pela discussão pública das posiçôes de cada um (cf. MANIN, 2007).

Mais difícil de compreender é a exclusão, na crítica a Kant, de uma referência ao conceito de "uso público da razão", mesmo porque o próprio Habermas, em obras posteriores à Direito e democracia, confere centralidade a esse conceito no quadro do "republicanismo kantiano" (HABERMAS, 1996b, p. 126; 2001, p. 140; cf. MELO, 2011; WERLE, 2008). Porém, mesmo nessas obras posteriores, o que está em jogo é a operacionalização do princípio moral kantiano como princípio de justiça no âmbito de um uso público da razão, sem que esse uso se esgote na argumentação moral. Enquanto tal, essa linha de raciocínio não está excluída em Direito e democracia. Ela seria a consequência natural do reconhecimento do ponto de vista moral para a fundamentação do conteúdo normativo dos direitos humanos, o que faltava a Rousseau. Desse modo, a adoção de um ponto de vista moral para a justificação de leis no interior de uma discussão pública pode ser vista como o elemento que tornaria, na interpretação habermasiana, o procedimento democrático em Kant mais complexo e amplo que em Rousseau. Em todo caso, convém observar que a 
referência posterior ao princípio kantiano de publicidade não altera em nada a crítica no que se refere ao problema da cooriginariedade, porque, no que concerne à crítica a Kant, o processo democrático continua a ter, aos olhos de Habermas, um papel subordinado em relação à fundamentação moral dos direitos, dada previamente, e porque nele mesmo o uso público se restringe ao uso moral da razão. Esse segundo aspecto só se revela, no entanto, quando se passa para a própria solução habermasiana do problema.

Para Habermas, a subordinação do direito à moral não é compatível com a autonomia política dos cidadáos, que confere legitimidade ao processo de legislação na medida em que eles se podem ver como autores das leis, às quais se submetem enquanto destinatários delas. Para fazer jus à prática de autonomia política, é preciso renunciar à ideia de direitos fundamentados moralmente que apenas esperam por sua positivação jurídica, determinando previamente o legislador político. Somente o princípio da democracia pode criar legitimidade, mas isso de maneira tal que os direitos subjetivos que garantem a autonomia privada, cuja substância é própria dos direitos humanos fundamentados moralmente, se constituem como condiçôes formais de possibilidade da autonomia pública. Desse modo, eles não são restriçôes às deliberaçóes do legislador político, mas antes condiçóes que as possibilitam, sendo eles mesmos, ao mesmo tempo, conteúdo de normas jurídicas a serem positivadas no processo legislativo. Nisso reside a ideia habermasiana de cooriginariedade de autonomia privada e autonomia pública, direitos humanos e soberania popular.

A ideia fundamental é que o princípio da democracia, o qual detém força de legitimação, se deve ao "[...] entrelaçamento do princípio do discurso e da forma direito” (HABERMAS, 1994, p. 154):

Esse entrelaçamento eu entendo como uma gênese lógica de direitos, que pode ser reconstruída passo a passo. Ela começa com a aplicação do princípio do discurso ao direito de liberdades subjetivas de ação em geral constitutivo como tal da forma direito - e termina com a institucionalizaçáo jurídica das condiçóes de um exercício discursivo da autonomia política, com a qual a autonomia privada posta [gesetzt] abstratamente de início pode ser configurada. Por isso o princípio da democracia só pode aparecer como cerne de um sistema de direitos. A gênese lógica desses direitos forma um processo circular, no qual o código do direito e o mecanismo para a geração de direito legítimo, isto é, o princípio da democracia, se constituem cooriginariamente. (HABERMAS, 1994, p. 154-5). 
O princípio do discurso (D) estabelece que "[...] são válidas somente as normas de ação com as quais todos os possíveis atingidos podem assentir enquanto participantes de discursos racionais" (HABERMAS, 1994, p. 138). O princípio do discurso se coloca, assim, em um plano a tal ponto abstrato que permanece indeterminada a natureza das normas de ação em questão, bem como o conjunto dos atingidos por elas, e ainda as formas particulares de discurso racional. Todas as determinaçôes dessas variáveis corresponderiam a especificaçóes distintas do princípio do discurso. Ou seja, ele pode se especificar como um princípio moral de universalização de normas, do qual o imperativo categórico é um modelo exemplar. Mas ele também pode se especificar - é do que se trata, na passagem acima - no caso da geração e justificação de direito positivo, como o princípio da democracia, segundo o qual somente podem pretender validade legítima as leis capazes de encontrar o assentimento de todos os parceiros do direito em um processo discursivo de positivação do direito. Não cabe aqui analisar a fundamentaçáo do princípio do discurso como tal, basta indicar que ele deriva das condiçóes simétricas de reconhecimento intersubjetivo discernidas no uso da linguagem orientada ao entendimento.

Mais complicada é, sem dúvida, a forma direito como tal, pois essa forma implica por si mesma direitos subjetivos de liberdade, independentemente de uma fundamentação moral. O fio condutor de Habermas é o conceito kantiano de legalidade, que combina coerção e liberdade. De um ponto de vista kantiano, a relação jurídica como tal não pode levar em conta a capacidade das pessoas em ligar sua vontade por meio de ideias normativas, mas apenas sua capacidade de tomar decisóes racionais com respeito a fins, isto é, a liberdade de arbítrio (HABERMAS, 1994, p. 144). A liberdade de arbítrio, acarretaria, por sua vez, a delimitação da forma jurídica às condiçóes externas da ação, detendo-se apenas na conformidade à lei. Porém, Habermas enfatiza que a liberação do arbítrio dos atores seria apenas o "verso da medalha" do caráter coercitivo de leis que limitam os espaços de ação a partir de fora. Dessa maneira, se o direito é formalmente coercitivo, como quer Kant, ele tem de implicar direitos de ação subjetivas que possibilitam a liberação do arbítrio. Só pode haver autorização para a coação, se há liberação da vontade em relação à obediência por dever à lei, como, inversamente, a obediência ao direito por motivos morais não pode estar ligada ao uso de coerção. Ora, tal liberação se constitui pelas liberdades subjetivas de ação asseguradas juridicamente e definidas negativamente. As características formais do direito pressupóem por si mesmas os direitos subjetivos entendidos como liberdades individuais para agir até onde é legalmente permitido, liberando nesse espaço normativamente 
neutro um enfoque meramente estratégico por parte do sujeito de direito. Nesse sentido, Habermas pode afirmar que o

[...] medium do direito como tal pressupóe direitos que definem o status de pessoas jurídicas como portadoras de direitos em geral. Esses direitos são talhados à medida do livre arbítrio de atores tipificados e individualizados [vereinzelte], isto é, à medida de liberdades subjetivas de ação que são acordadas de maneira condicional. (HABERMAS, 1994, p. 151).

Não é necessário fundamentar moralmente tais direitos subjetivos que garantem a autonomia privada dos sujeitos de direito, porque eles são inerentes à forma jurídica como tal. Ora, a forma jurídica, em seu sentido moderno, isto é, dotada de um caráter positivo, coercitivo e individualista, foi antes de tudo uma inovação evolutiva da modernidade, capaz em princípio de possibilitar a integraçáo social diante da desvalorização de um ethos substancial que liberou uma pluralidade axiológica cada vez mais extensiva. Certamente, é possível uma relação de complementação funcional entre moral e direito, na medida em que a moral universalista se encontra diante do mesmo problema de integração, ou seja, encontrar o ponto de vista que possibilita discernir o que é bom para todos na multiplicidade de visões de mundo e interesses em conflito. Mas por si mesma ela não pode justificar as propriedades formais do direito. Reside nisso a chamativa tese habermasiana de que "[...] a forma direito não é de modo geral um princípio que se deixe 'fundamentar', seja epistêmica seja normativamente" (HABERMAS, 1994, p. 143).

O sistema de direitos que surge do entrelaçamento do princípio do discurso e da forma direito é apresentado em uma sequência de cinco categorias de direitos fundamentais. As três primeiras categorias formam o código jurídico, pois determinam o status das pessoas de direito. Basicamente, trata-se aqui dos direitos que garantem as liberdades subjetivas de ação, dos direitos que estabelecem o status de membro de uma associaçáo jurídica e, por fim, os direitos que garantem a possibilidade de postulação judicial e proteção jurídica das pessoas individuais (HABERMAS, 1994, p. 155-6). Essas três primeiras categorias de direito garantem a autonomia privada dos sujeitos de direito unicamente no sentido de eles se reconhecerem mutuamente como destinatários da lei. Somente a quarta categoria permite que esses sujeitos de direito assumam também o status de cidadãos, isto é, de autores da própria ordem jurídica. Trata-se aqui dos direitos de participaçáo igual nos processos de formação da opiniáo e da vontade. Essa quarta categoria, que garante a 
autonomia pública, tem um caráter reflexivo, já que possibilita interpretar e configurar concretamente em termos jurídicos tanto as primeiras categorias como a si própria. Na configuração política de todas essas categorias, surge uma relação de implicação delas com a quinta categoria dos direitos fundamentais de bem-estar social, técnico e ecológico, isto é, direitos sociais, em sentido amplo, que permitem materialmente o exercício da autonomia privada e pública.

É de se observar que essas categorias são introduzidas em abstrato, sem um conteúdo particular, variável conforme o contexto sociopolítico. É somente com a quarta categoria que todos os direitos fundamentais recebem uma positivação jurídica concreta. Esse aspecto é importante para entender como as três primeiras categorias, que sustentam a autonomia privada, se relacionam com a quarta, que garante a autonomia pública. No papel de autores, os cidadãos já não dispõem mais de nenhuma outra linguagem que não envolva as três primeiras categorias do direito. É nesse sentido que elas possibilitam a autonomia pública, sem restringi-la, ao mesmo tempo em que, por meio da autonomia pública, as três primeiras recebem uma positivação jurídica concreta. Com isso se tornaria compreensível a cooriginariedade de autonomia pública e privada. Enquanto linguagem própria do direito, as categorias dos direitos privados não podem ser vistas "[...] como direitos naturais ou morais, que apenas esperam ser colocados em vigor", nem podem "ser meramente instrumentalizados para fins de uma legislação soberana" (HABERMAS, 1994, p. 161), ao preço de se ferir o médium do direito.

Além disso, há uma relação de implicação material entre a autonomia privada e a autonomia pública. $\mathrm{O}$ direito de comunicação e de participação no processo de formação da vontade e da opinião é instaurado com a quarta categoria, sendo institucionalizado e regulado juridicamente, de modo que os pressupostos de igualdade e simetria, inscritos nas condiçóes de possibilidade de um discurso isento de dominação, recebem uma configuração jurídica determinada. Porém, a liberdade comunicativa de tomar posição de sim ou não em relação às normas pressupóe igualmente uma liberdade negativa de abster-se. Seguindo Klaus Günther, pode-se dizer que não haveria liberdade comunicativa se não houvesse também a liberdade negativa de não participar da comunicação pública, o que por sua vez é garantido pelas leis que sustentam a autonomia privada (cf. GÜNTHER, 1998, p. 236). Estas sustentam a independência e a privacidade necessárias para uma participação livre e qualificada na esfera pública. Por sua vez, a distribuição igual de liberdades 
privadas depende do exercício autônomo das liberdades políticas postas em total simetria. A forma direito não implica por si mesma uma distribuição igual de direitos. Esse aspecto, essencial para a legitimação da ordem jurídica, tem de ser buscado nos procedimentos de participação equânime no processo de formação da vontade.

Em suma, os direitos subjetivos que garantem a autonomia privada se apresentam como condiçóes de possibilidade dos direitos políticos em dois sentidos: primeiro, porque constituem a linguagem jurídica da democracia, o medium em que ela se exerce, firmando o conceito de pessoa jurídica entendida como destinatária das leis; em segundo lugar, porque a autonomia privada ela mesma é uma condição indispensável para a participação autônoma na discussão pública sobre as leis. Também em dois sentidos os direitos de liberdade de ação acarretam os direitos políticos: aquelas categorias jurídicas não podem ser positivadas e concretizadas sem os direitos que tornam os destinatários autores das leis que eles devem obedecer, e as liberdades subjetivas não poderiam em princípio ser distribuídas igualmente sem a participação simétrica de todos os cidadãos no processo de formaçáo da vontade e da opiniáo.

Embora Habermas exponha a gênese lógica do sistema dos direitos em uma sequência determinada de categorias, náo se pode perder de vista que se trata, no caso de uma regulação democrática do convívio por meio do direito, de uma instauração simultânea das quatro categorias. $\mathrm{O}$ processo democrático tem de instaurar de uma só vez a sua linguagem jurídica, que como tal implica liberdades subjetivas, e a si mesmo, isto é, seu procedimento de legitimação, a participação igual de todos os cidadãos. A questão de quais liberdades de ação e quais direitos de participaçáo devem ser positivados tem de ser remetida a história. Cada constituição interpreta, no horizonte da história de cada coletividade política, o conteúdo concreto das categorias de direitos fundamentais, mais ainda, ela continua a reinterpretá-lo no horizonte de novas experiências e conflitos que vão surgindo nas esferas públicas respectivas. A reconstrução do sistema dos direitos fundamentais se restringe, por isso, à tentativa de explicar o significado de uma práxis constituinte que pretende regular democraticamente o convívio de todos por meio do direito positivo. Ela não predetermina em concreto nenhum direito fundamental.

A princípio, portanto, Habermas parece proteger o princípio de legitimação dos direitos fundamentais de qualquer recurso a concepçóes éticas do bem comum ou a pontos de vista morais sobre o justo. O procedimento democrático e a forma direito impóem condiçôes normativas que são neutras, 
a princípio, tanto em relação à ética como à moral. Contudo, isso não significa dizer que a justificação e a criação democrática de direitos podem se desenvolver independentemente de valores e princípios. O procedimento democrático, ao ser remetido ao horizonte histórico concreto de uma coletividade política, se abre a diferentes tipos de discursos e procedimentos, destinados a legitimar o conteúdo dos direitos fundamentais. Concepçóes sobre o que é bom para o nós de uma coletividade, à luz de uma tradição ético-política, bem como princípios morais de justiça sobre o que é igualmente bom para todos, desempenham, assim, papéis determinantes para a legitimidade do direito. Tal é a complexidade do processo democrático, que ele tem de contar também com discussôes sobre a realização de fins coletivos e negociaçôes sobre interesses de grupo não-generalizáveis.

Dessa maneira, as liberdades subjetivas, igualmente distribuídas, podem encontrar uma fundamentaçáo moral no interior mesmo do processo democrático. Porém, se o princípio moral deve poder discernir o que é igualmente bom para todos - protegendo a autonomia privada de cada um - é somente o procedimento democrático, ao legalizar um uso público das liberdades comunicativas em toda sua extensão, que permite discernir se a própria operacionalização do princípio moral não está contaminada desde o início por valores determinados e particulares. Daí que, em última instância, os direitos humanos fundamentados moralmente só poderem encontrar legitimidade no interior do discurso democrático, aberto a autocorreçóes normativas.

Segundo Habermas, nem Rousseau nem Kant chegaram aonde pretendiam chegar. Se o próprio Habermas o consegue, é uma questão que vem sendo debatida. Todavia, convém se perguntar até que ponto o esquema de Habermas não se alimenta dos outros dois. De Rousseau, é evidente a inspiraçáo de um projeto de democracia radical que principia pelas condiçóes político-jurídicas da liberdade como autonomia. Tal como Rousseau, Habermas não conta senão com o processo democrático segundo o princípio da soberania popular. É no interior desse mesmo processo, contando suas condiçóes jurídicas e políticas, que é possível encontrar o seu nexo com a autonomia privada de cada um. Por conseguinte, Rousseau representa a perspectiva correta a respeito de onde é possível encontrar o nexo entre direitos humanos e democracia. Entretanto, ele erra no como encontrar tal nexo. A substância ética que o Contrat social associa à vontade geral faz a autonomia civil pesar demais sobre a autonomia privada. De outro lado, essa náo pode ser garantida unicamente pela forma de leis gerais, visto que a universalidade legal em si mesma náo explicita por que a autonomia 
privada de todos e em pé de igualdade tem de ser garantida. Ao mesmo tempo, é evidente que a ideia rousseauísta de uma linguagem jurídica que constitui a soberania é igualmente aproveitada por Habermas, mas desenvolvida a partir de outro lado, isto é, da relação constitutiva das liberdades subjetivas com a forma direito descoberta por Kant.

Assim, basta para Habermas afastar a forma direito de seu vínculo moral, a fim de que ele possa aproveitar também a ideia kantiana de um sistema de direitos fundamentais capaz de demonstrar, no seu processo de constituição democrática, a pressuposição recíproca entre as categorias jurídicas. Mas se poderia acrescentar que, do ponto de vista de Habermas, Kant foi mais longe que Rousseau, ao transformar a soberania popular em um procedimento democrático que permite discernir moralmente o interesse simétrico de todos. Kant provoca uma dessubstancialização no conceito rousseauísta de soberania popular que Habermas trata de radicalizar, com sua teoria do discurso. Porém, tal radicalização deve corrigir ainda a sobrecarga moral que Kant sugere ao antepor direitos morais ao legislador. $\mathrm{O}$ procedimento democrático, se ele deve se abrir para a fundamentação moral dos direitos humanos, não pode delimitar de antemão o pleno uso público das liberdades comunicativas, que inclusive possibilitam a correção sobre realizaçóes particulares de princípios morais de justiça.

Tudo se passa, portanto, como se Habermas corrigisse a abordagem geral de um pela de outro, pois o que ele identifica nelas de maneira crítica são perspectivas parciais que poderiam se complementar. Todavia, isso significa pressupor uma instância crítica que está além dessas duas abordagens parciais. Como ela seria possível? Como já dito, as deficiências de ambas as abordagens devem ser colocadas, para Habermas, na conta do paradigma da filosofia da consciência. Por que Rousseau e Kant partem de concepçóes de sujeito, ainda que diferentes em suas dimensôes, a práxis de autodeterminação política acaba sendo ignorada em sua dimensão intersubjetiva. Somente por uma reconstrução dos pressupostos pragmáticos da ação comunicativa e do discurso seriam dadas as condiçóes de resgatar o conteúdo normativo que liga autonomia privada e autonomia pública (ou liberdade negativa revestida pela forma direito e a liberdade comunicativa do discurso). Não cabe aqui aprofundar tal reconstrução. Para a discussão, interessa propriamente o seu resultado, que, ao meu ver, pode ser descrito como uma estratégia de redução peculiar de normatividade nos dois princípios, que, a rigor, demonstra a cooriginariedade entre soberania popular e direitos humanos, ou seja, o 
princípio do discurso e a forma direito. Quanto mais eles podem ser mostrados como normativamente neutros em relação a valores e princípios morais e como absolutamente procedimentais, tanto mais eles permitem o uso público reflexivo e inclusivo sobre as liberdades, em geral. E tanto mais a filosofia deve entregar ao processo democrático concreto a tarefa de definir sempre de novo os limites entre essas liberdades (HABERMAS, 1996b, p. 126).

Portanto, é a imparcialidade e a neutralidade próprias desses dois princípios que possibilitam radicalizar a democracia para encontrar nela e em sua linguagem jurídica as condiçóes fundamentais da autonomia pública e privada. $\mathrm{O}$ procedimentalismo radicalizado de Habermas, mais abstrato em termos normativos, pretende, assim, a partir de suas características formais, se alçar para fora da concorrência entre os dois princípios, a fim de fazê-los entrar em acordo, pois os modelos em que eles se desenvolvem já estavam prédeterminados normativamente de antemão.

REPA, Luiz. The co-originality between human rights and popular sovereignty: Habermas's critique of Rousseau and Kant. Trans/Form/Ação, Marília, v. 36, p. 103-120, 2013. Edição Especial.

ABSTRACT: This text analyzes and evaluates the influence of the political philosophies of Rousseau and Kant in Habermasian thought. It stresses the fundamental idea of Faktizität und Geltung, according to which there is a logical co-originality of human rights, interpreted as fundamental rights of individual liberty, and popular sovereignty, understood as political rights of participation and communication in the process of public formation opinion and will. It is argued that Habermas' critique of Rousseau and Kant is due to Habermas' project of the radicalization of democracy, to which the contributions of the two philosophers present some obstacles. Nevertheless, it may be said that, according to Habermas, the contribution of each one serves to solve the problems in the contribution of the other.

KEYWORDS: Fundamental rights. Popular sovereignty. Democracy. Autonomy. 


\section{REFERÊNCIAS}

DUTRA, D. J. V. Rousseau e Habermas. Argumentos, ano 4, n. 18, 2012.

GÜNTHER, K. Communicative Freedom, Communicative Power, and Jurisgenesis. In: ROSENFIELD, M.; ARATO, A. (Org.). Habermas on law and democracy. Berkeley: University of California Press, 1998.

HABERMAS, J. Volkssouveränität als Verfahren. In: Faktizität und Geltung. Frankfurt am Main: Suhrkamp, 1988/1994.

Notas programáticas para a fundamentação de uma ética do discurso. In: Consciência moral e agir comunicativo. Trad. Guido de Almeida. Rio de Janeiro: Tempo Brasileiro, 1989.

. Faktizität und Geltung. Frankfurt am Main: Suhrkamp, 1994.

. Drei normative Modelle der Demokratie. In: Die Einbeziehung des Anderen. Frankfurt am Main: Suhrkamp, 1996a.

. Vernünftig” versus “wahr” - oder die Moral der Weltbilder. In: Die Einbeziehung des Anderen. Frankfurt am Main: Suhrkamp, 1996b.

. Der demokratische Rechtsstaat - eine paradoxe Verbindung widersprüchlicher Prinzipien? In: Zeit der Übergänge. Frankfurt am Main, 2001.

KANT, I. MS: Die Metaphysik der Sitten. In: Akademieausgabe von Immanuel Kants Gesammelten Werken, vol. VI.

. UG: Über den Gemeinspruch: Das mag in der Theorie richtig sein, taugt aber nicht für die Praxis. In: Akademieausgabe von Immanuel Kants Gesammelten Werken, vol. VIII.

MANIN, B. Legitimidade e deliberação política. In: WERLE, D. L.; MELO, R. S. Democracia deliberativa. São Paulo: Esfera Pública, 2007.

MAUS, I. Liberties and Popular Sovereignty: On Habermas's Reconstruction of the System of Rights. In: BAYNES, K.; SCHOMBERG, R. Essays on Habermas's "Between Facts and Norms". Albany: Suny, 2002.

MELO, R. S. O uso público da razão. Pluralismo e democracia em Jürgen Habermas. São Paulo: Loyola, 2011.

ROUSSEAU, J-J. Du contrat social. Paris: Flammarion, 2001.

WERLE, D. L. Justiça e democracia. Ensaios sobre John Rawls e Jürgen Habermas. São Paulo: Esfera Pública, 2008. 
REPA, L. 